\section{Countries of Central America need to invest more in HIV/AIDS prevention $^{1}$}

Key words: acquired immunodeficiency syndrome, HIV infections, health expenditures, cost-benefit analysis, Central America.

\footnotetext{
1 Based on: (1) World Bank. HIV/AIDS in Central America: an overview of the epidemic and priorities for prevention. Available from: http:/ / www.worldbank.org [Web site]. Accessed 26 November 2003. (2) World Bank. To control AIDS epidemic, Central America must invest more on prevention [press release]. Available from: http://www.worldbank.org [Web site]. Accessed 16 October 2003.
}

Four of the six countries in Latin America with the highest HIV prevalence rates among adults are in Central America, where the epidemic threatens to run out of control unless prevention efforts are intensified, according to report issued in October 2003 by the World Bank. The report was produced in conjunction with the Third Central American Congress on Sexually Transmitted Diseases/HIV/ AIDS, which was held 13-17 October in Panama. Among the countries of Latin America, Belize, Honduras, Panama, and Guatemala were four of the six nations with the highest HIV prevalence levels as of the end of 2001.

"The HIV / AIDS epidemic in Central America is increasingly serious, and although the epidemic continues to be concentrated in high-risk populations, it is becoming generalized in some countries," said Jane Armitage, the World Bank's Director for Central America. "Fortunately, we are still on time. Prevention is the key."

\section{TRANSMISSION PATTERNS IN CENTRAL AMERICA}

The new World Bank report is entitled HIV/ AIDS in Central America: An Overview of the Epidemic and Priorities for Prevention. According to the report, HIV adult prevalence rates in Central America are highest in Belize (2.0\%), Honduras (1.6\%), Panama $(1.5 \%)$, and Guatemala (1.0\%). The two other countries in Latin America with similarly high rates are Guyana (2.7\%) and Suriname (1.2\%).

The rates in the other countries of Central America are: El Salvador (0.6\%), Costa Rica (0.6\%), and Nicaragua $(0.2 \%)$. Despite the relatively low levels that those three countries now have, if current trends continue, the epidemic could reach prevalence levels of close to $2 \%$ in those nations by the year 2010.

HIV transmission in Central America is primarily due to heterosexual sex, a pattern that is more similar to what is seen in the Caribbean than in South America (see the sidebar entitled "Latin America must deal with a range of problems in combating the HIV/AIDS epidemic"). Because of that tendency in Central America, although there are now more men than women with AIDS in the area, the gender gap is closing, according to the World Bank report.

The HIV / AIDS epidemic in Central America is generally concentrated in high-risk populations such 
as commercial sex workers, men who have sex with men, prisoners, street children, and police and military forces. In Honduras another high-risk group are the Garifuna, a population of Afro-Caribbean heritage. Two exceptions to these typical patterns for Central America are Belize, where the disease is becoming generalized in some areas of the country, and Nicaragua, where the epidemic is still nascent.

Commercial sex workers in Central America are at high risk of HIV infection because their customers frequently do not uses condoms. Sex workers often do not insist on the use of condoms since they underestimate the risk of infection, they do not have access to condoms, or they earn more money by providing unprotected sex. Clients of sex workers act as a bridge between high-risk groups and the general population.

\section{COST-EFFECTIVENESS MODEL FOR ALLOCATING LIMITED FUNDS}

A substantial impact on the HIV/AIDS epidemic in Central America can be achieved even with limited resources, provided they are channeled to the most cost-effective interventions. That is according to a decision-making tool, called the Allocation by Cost-Effectiveness (ABC) Model, that the World Bank developed in 2002 in order to help officials determine the resource allocation that would prevent the highest number of new infections for any given budget level. The model can also be used to simulate the effect of alternative budget decisions and to generate consensus on the HIV prevention interventions that could have the greatest impact.

The ABC Model focuses only on prevention programs and does not consider tradeoffs between paying for prevention rather than treatment and care. The model analyzes alternative resource allocations differentiated by strategy and target population group, as defined by risk behavior, sexual orientation, gender, and other characteristics.

The ABC Model was applied in country-level workshops in Guatemala, Honduras, and Panama between May 2002 and August 2003. During those workshops, initial estimates made with the model were reviewed by national and international experts in order to reach broader consensus and to produce "ownership" of the final results.

From the workshops it became clear that even limited but well-spent resources could slow the spread of HIV/AIDS. In the three countries the most cost-effective interventions were identified as: condom social marketing; free condom distribution targeted to high-risk groups; information, education, and communication for high-risk groups, in-
Latin America must deal with a range of problems in combating the HIV/AIDS epidemic

The countries of Latin America have increased their efforts to prevent the spread of HIV/AIDS, but there is still need for better use of resources, stronger HIV/ AIDS surveillance, and broader civil society participation, according to a comprehensive study issued by the World Bank in November 2003. Entitled HIV/AIDS in Latin American Countries: The Challenges Ahead, the report presents the results of a detailed examination conducted in 17 countries of Latin America. The study is based on information supplied by governments, physicians, and civil society organizations with extensive experience in HIV/AIDS prevention and treatment. Data for the report also came from national statistics, international organizations, and from studies undertaken in the area.

"Latin America has the organizational infrastructure and the community of professionals for sustained programs to counter the disease," said Anabela Abreu, the report's principal author. "If the warning signs are heeded, and appropriate prevention measures taken in the very near future, Latin America has the opportunity to avoid the sad outcomes seen in other regions."

According to the study, the overall prevalence of HIV among persons 15 to 49 years old in Latin America is $0.5 \%$. However, underreporting is so common that there are likely to be $30 \%$ more cases of AIDS and $40 \%$ more cases of HIV than existing statistics show. While heterosexual sex is the primary mode of HIV transmission in Central America, sex between men is the leading mode in South America. In the Southern Cone countries, injecting drug use also plays a major role in transmission. While the majority of persons living with HIV in Latin America are male, the gender gap is closing. HIV/AIDS has already leapt from high-risk groups into the general population in Brazil and Honduras.

The World Bank study lists several major problem areas that the countries of Latin America must deal with if they are going to keep the HIV / AIDS epidemic from broadening. With prevention, for example, there are too few interventions focusing on highrisk groups, which is made worse by a substantial lack of information on the magnitude and trend of the epidemic. While health and sexual education programs for adolescents and young people are widespread, those persons may still lack the skills to prevent HIV infection. There are structures in place for multisec- 
toral coordination in almost all the countries of Latin America, but the level of true collaboration is still low, and there is a shortage of needed resources. Further, there is limited coordination between nongovernmental organizations (NGOs) and governments in the interventions with specific populations. One solution would be to ensure a stronger and continuous involvement from civil society; that may be the only way to expand the response to HIV/AIDS in the near future. Interventions also need to be intensified to target high-risk groups.

Another problem area is the availability of health and social services. Many people in Latin America who are infected with HIV do not have access to adequate, comprehensive care. Insufficient medical training also impacts the level and quality of care. High costs and limited health infrastructures hinder access to antiviral drug therapies. There are too few laboratories that can perform needed HIV diagnostic tests. Barriers such as discrimination and lack of confidentiality make it difficult for persons to find out their HIV status and for infected individuals to receive early treatment. These shortcomings could be overcome by improving health and social services through multisectoral collaboration. HIV testing should be promoted, particularly among high-risk groups and pregnant women. More physicians and nurses should receive training in clinical management and treatment of HIV and other sexually transmitted infections.

Human rights is another area of concern in Latin America. Lack of information, stigmatization, homo- phobia, and social prejudices regarding sexual orientation or behavior impede access to prevention and clinical care. This issue can be dealt with by preserving the rights of all persons to health, social, and psychological care; promoting programs addressing the schooling of HIV-positive children; and promoting the right of HIVpositive individuals to work and to being integrated or re-integrated in the workforce.

Another concern in Latin America is the countries' capacity in the areas of structure and management. Most of the nations have a multisectoral plan to deal with HIV/AIDS, but insufficient technical and political capacity and the limited resources for HIV/ AIDS control have weakened collaborative responses to the epidemic. Surveillance systems in Latin America need to be strengthened so they can provide more accurate data for decision-making, and the systems also need to incorporate a behavioral component. Other possible remedies include establishing guidelines for prevention interventions and consolidating the interventions that have been most cost-effective; revising blood safety policies so as to achieve universal testing of donated blood and the acceptance of only voluntary, altruistic, nonremunerated donations; providing continuous capacity-building for personnel; overcoming cultural, social, and religious factors that obstruct good technical proposals or government decisions; and encouraging NGO networks.

The complete report from the World Bank can be viewed and downloaded for free from the World Bank Web site (http:/ / www.worldbank.org). cluding men who have sex with men, commercial sex workers, and prisoners; and voluntary counseling and testing.

Using that optimal allocation of funds, US\$ 1 million would prevent between 5100 and 12000 infections. The corresponding cost per infection prevented would be between US\$ 84 and US\$ 196.

A second key finding of the workshops was that with a budget of US\$ 10 million, only about 25\% of all primary and secondary HIV infections can be prevented. That is because it is hard to reach the population groups that have the highest risk. For example, the workshop participants in the three countries estimated that any given intervention can only reach between $40 \%$ and $70 \%$ of commercial sex workers and only some $25 \%$ of men who have sex with men. That finding leads to the conclusion that after a cer- tain budget level, the government should not only fund traditional prevention interventions but also develop strategies to reach a higher proportion of high-risk groups. This could be done, for example, through such efforts as decriminalization, reduction of stigma, and increased service coverage.

The results from the workshops indicate that spending for HIV prevention in Central America has been far from adequate. In 2000 the total of public and private funding for HIV-related public health and prevention activities was US\$2.8 million in Guatemala, US\$ 6 million in Honduras, and US\$ 900000 in Panama. However, these resources were not well targeted towards the high-impact prevention activities identified in the workshops.

Nevertheless, the modeling exercise should help officials in Central American countries to work 
more productively in the future with the Global Fund for AIDS, TB and Malaria; the United States' Agency for International Development; and other external donors.

The complete report from the World Bank can be viewed and downloaded for free from the Web site of the World Bank at http: / / www.worldbank.org.

\section{SINOPSIS}

\section{Los países de Centroamérica necesitan invertir más en la prevención de la infección por el VIH y el sida}

Cuatro de los seis países latinoamericanos con la mayor prevalencia de infección por el virus de la inmunodeficiencia humana (VIH) en adultos se encuentran en Centroamérica, subregión donde la epidemia amenaza con volverse incontrolable si no se intensifican las medidas dirigidas a combatirla, afirma un informe emitido por el Banco Mundial en octubre de 2003. La prevalencia de la infección por VIH en adultos es mayor en Belice (2,0\%), Honduras (1,6\%),
Panamá (1,5\%) y Guatemala (1,0\%) que en El Salvador $(0,6 \%)$, Costa Rica $(0,6 \%)$ y Nicaragua $(0,2 \%)$. A pesar de que en estos últimos tres países la prevalencia de la infección por VIH es relativamente baja en estos momentos, podría aproximarse a 2,0\% para el año 2010 si continúa la tendencia actual. La transmisión del VIH en Centroamérica ocurre fundamentalmente por la vía sexual entre personas heterosexuales, un patrón más parecido al observado en el Caribe que en América del Sur. Debido a esa tendencia, se está cerrando la brecha existente actualmente en Centroamérica entre el número de hombres y de mujeres con sida, todavía caracterizada por una mayor proporción de hombres infectados. Se podría lograr un gran impacto en el control de la epidemia de infección por VIH y sida en Centroamérica, incluso con recursos limitados, si los fondos se encauzaran hacia intervenciones más eficaces en función del costo. Entre las intervenciones que podrían tener mayor impacto se encuentran la comercialización social del condón; la distribución gratuita de condones entre personas pertenecientes a grupos en alto riesgo; la información, la educación y la comunicación dirigidas a los grupos en mayor peligro, incluidos los hombres que tienen relaciones sexuales con otros hombres, los trabajadores sexuales y los presidiarios; y el acceso a asesoramiento y a pruebas de detección voluntarias. 